\title{
Analysis of mating systems in the schistosome-vector hermaphrodite snail Bulinus globosus by DNA fingerprinting
}

\author{
P. JARNE, B. DELAY, C. BELLEC*, G. ROIZES $\uparrow \&$ G. CUNY† \\ Université Montpellier II, Institut des Sciences de l'Evolution, Génétique et Environnement, Place Bataillon, 34095 \\ Montpellier Cedex 05 *ORSTOM, 2051 avenue du val de Montferrand, BP 5045, 34032 Montpellier Cedex I and tUPR \\ 8402 CNRS-U 249 INSERM, Institut de Biologie, Boulevard Henri IV, 34060 Montpellier Cedex, France
}

\begin{abstract}
Bulinus globosus, one of the intermediate hosts for Schistosoma, is a hermaphrodite freshwater snail. Multilocus DNA fingerprinting was applied in order to investigate the mating system of this facultatively self-fertilizing species. By analysing DNA fingerprints of eight broods, we have shown that selfed and outcrossed individuals could be unambiguously distinguished by comparison with their parent fingerprints. First, selfed offspring patterns shared a higher number of bands with their mother than did outcrossed ones. Secondly, at least three paternal bands could be detected per outcrossed offspring pattern.
\end{abstract}

Keywords: DNA fingerprinting, mating systems, snails, schistosome vector.

\section{Introduction}

Minisatellite DNA loci or a variable number of tandem repeats (VNTR) are short DNA fragments constituted of tandemly repeated short sequences of typically 10-60 bp (Jeffreys et al., 1985; Nakamara et al., 1987). The large amount of variation in the number of repeated sequences results in a high number of alleles per locus. The 33.6 and 33.15 human minisatellite sequences, when used as probes in humans, reveal a number of loci simultaneously (Jeffreys et al., 1985), producing highly variable patterns called fingerprints; the probability that two individuals (except twins or individuals in highly inbred mating systems) share the same pattern is very low. Moreover, the bands revealed are inherited in a standard Mendelian way (Jeffreys et al., 1985) which has allowed fingerprinting to be used in pedigree analyses (Jeffreys et al., 1985; Jeffreys et al., 1986; Burke, 1989). Wide applications of this technique have been found when human probes were shown to give similar results in other mammals (Jeffreys \& Morton, 1987), in birds (Burke \& Burford, 1987; Wetton et al., 1987; Meng et al., 1990) and even in plants (Dallas, 1988). It was recently shown that fingerprinting is also possible in the schistosome-vector snail Bulinus globosus (Jarne et al., 1990).

This snail is involved in bilharziasis transmission throughout Africa (Brown, 1980). Understanding its population dynamics requires the analysis of its mating system (Rollinson, 1984). B. globosus is a hermaphrodite and can self-fertilize, however, it cross-fertilizes when paired. Foreign sperm from multiple partners can be stored and remains viable for several months after copulation (Rudolph, 1983; Rudolph \& Bailey, 1985). Two genetic markers have been used to investigate the mating system in hermaphrodite freshwater snails but are of limited use. First, pigment markers (Richards, 1973; Rudolph, 1983; Rudolph \& Bailey, 1985) not only limit the analysis to pairs of individuals, but marked strains, which are often constituted by repeated self-fertilization, may show artificial differences in fitness among strains (Vianey-Liaud, 1989; Rollinson et al., 1989). Secondly, the allozymic variability in B. globosus is too low (Jelnes, 1986) to be of much use. Fingerprinting shows none of these drawbacks.

In our investigation of mating systems by DNA fingerprinting, we show that selfed and outcrossed offspring can be unambiguously identified. For this purpose, we have analysed pure selfed, pure outcrossed and mixed broods from different individuals.

\section{Materials and methods}

\section{Snails}

A strain was constituted with snails that originated from Daikana, Niger. Snails used in these experiments 
were second generation laboratory animals. The number of snails studied is indicated in Table 1 . They were reared at $25^{\circ} \mathrm{C}$ with an artificial photoperiod of $12 \mathrm{~L} / 12 \mathrm{D}$ and fed with boiled lettuce. Water was changed every 2 days. Snails were isolated until sexual maturity, which occurred around 70 days. The analyses were performed on three types of brood. The first type was the pure outcrossed brood: three couples of mature snails were paired during 1 week to ensure cross-fertilization (Rudolph, 1983). They were then isolated and the egg capsules of one individual per group (mother) were collected during 1 week. The second type was the pure selfed brood: the egg capsules of three virgin mature snails were collected during 1 week. The third type was the mixed selfed/ outcrossed brood: the egg capsules of two virgin mature snails (mother) were collected during 1 week. These mother snails were then paired each with one snail (father) during 1 week and isolated again. The egg capsules of the mothers were collected during 1 week. The young snails were reared singly until they were large enough for DNA extraction (7-8 mm in length).

\section{DNA fingerprinting}

DNA extraction was performed by modifying standard protocols (Maniatis et al., 1982). Individual snails were extracted from their shell and the digestive gland was removed. They were then frozen in liquid nitrogen and crushed in a powder. The powder was mixed with $2 \mathrm{ml}$ of $50 \mathrm{~mm}$ Tris- $\mathrm{HCl}, 100 \mathrm{~mm}$ EDTA, $\mathrm{pH} 8$, containing 1 per cent SDS, $0.8 \mathrm{mg} / \mathrm{ml}$ Proteinase-K and 2 per cent $\beta$-mercaptoethanol and incubated for $3 \mathrm{~h}$ at $55^{\circ} \mathrm{C}$. DNA was isolated by phenol/chloroform extraction and precipitated by the addition of $0.1 \mathrm{vol}$. Na acetate ( $3 \mathrm{~m}, \mathrm{pH} 7$ ) and 3 vol. absolute ethanol. The precipitated DNA was washed twice in 70 per cent ethanol, air-dried and redissolved in $200 \mu \mathrm{l} 1 \times \mathrm{TE}$ buffer. For the fingerprinting analysis, $10 \mu \mathrm{g}$ of an individual's DNA was digested overnight at $37^{\circ} \mathrm{C}$ using 25 units of Hinf $\mathrm{I}$ (Boehringer) in the appropriate buffer. Digested

Table 1 Number of offspring analysed for each pair of snails in cross-fertilization and each single self-fertilization

\begin{tabular}{|c|c|c|c|c|}
\hline \multirow[b]{2}{*}{ Brood } & \multirow{2}{*}{$\begin{array}{l}\text { Pure outcrossed* } \\
\text { brood }\end{array}$} & \multirow{2}{*}{$\begin{array}{l}\text { Pure selfed } \\
\text { brood }\end{array}$} & \multicolumn{2}{|c|}{ Mixed brood } \\
\hline & & & Selfed & Outcrossed \\
\hline 1 & 8 & 5 & 4 & 9 \\
\hline 2 & 9 & 7 & 4 & 8 \\
\hline 3 & 13 & $11 \dagger$ & & \\
\hline
\end{tabular}

* These snails were probed only with 33.15 .

$\dagger$ These snails were probed only with 33.6.
DNAs were electrophoresed in 0.8 per cent agarose gels for $40-45 \mathrm{~h}$ at $1.5 \mathrm{~V} / \mathrm{cm}$ and blotted onto Amersham Hybond- + nylon membranes by the pocket-blotting technique (Cuny et al., 1991). The membranes were prehybridized for $3 \mathrm{~h}$ at $68^{\circ} \mathrm{C}$ in $1.5 \times \mathrm{SSPE}, 0.5$ per cent dried non-fatty, milk powder, 1 per cent SDS and $50 \mathrm{~g} / \mathrm{ml}$ of Escherichia coli DNA $\left(2 \mathrm{ml} / 10 \mathrm{~cm}^{2}\right.$ of membrane). They were hybridized overnight in the same solution $\left(1 \mathrm{ml} / 10 \mathrm{~cm}^{2}\right.$ of membrane) supplemented with 10 per cent dextran sulphate, in the presence of the 33.6 or 33.15 probes (Jeffreys et al., 1985). The probes were labelled with $\alpha-{ }^{32} \mathrm{P}$ dCTP by random oligonucleotide priming (Feinberg \& Vogelstein, 1983). The membranes were

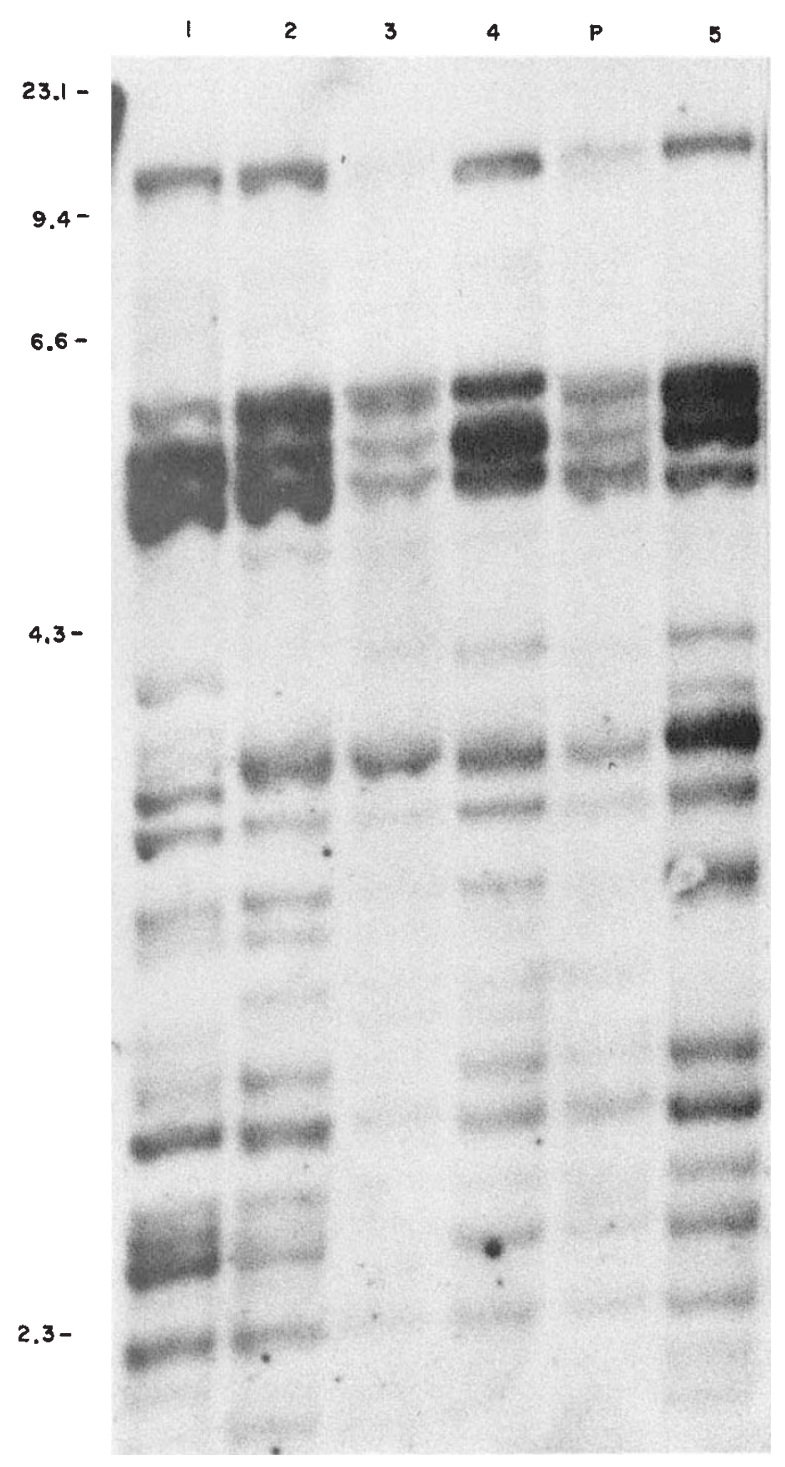

Fig. 1 DNA fingerprints from one individual $(\mathrm{P})$ and five of its selfed offspring $(1-5)$. Band size $(\mathrm{kb})$ is indicated on the left. 
washed twice for $20 \mathrm{~min}$ at $68^{\circ} \mathrm{C}$ in a $2 \times \mathrm{SSPE}, 0.1$ per cent SDS solution. Autoradiography was undertaken at $-80^{\circ} \mathrm{C}$ for $3-5$ days with intensifying screens.

\section{Fingerprints analysis}

Fingerprints were analysed by visual inspection for the presence of bands of the same apparent molecular weight and relative intensity. A higher number of bands was analysed in pure selfed broods, because there was no mistake in assigning maternal and paternal bands of slightly different molecular weight, which was not the case in outcrossed broods. Bands were scored between 23 and $2.3 \mathrm{~kb}$.

In the following, fixed bands refer to those present in all offspring (so apparently homozygosity in parent), whereas variable bands are those found segregating (hence heterozygous in parents). In pure selfed broods, a band transmitted to all offspring cannot be assigned to one of these two categories of bands because of the high expected-transmission ratio of heterozygous loci ( 75 per cent) and the low number of offspring in four among the five broods studied. Thus, we measured the total number of bands and calculated their mean transmission frequency.

We counted the number of variable bands and the total number of bands in the pure outcrossed broods and estimated the mean transmission frequency. Variable parental transmission in outcrossed offspring was compared to the expected value with a 50 per cent segregation ratio, using a $\chi^{2}$ test ( 1 d.f.). We then compared the number of bands out of the total number of variable bands $(n)$ which were transmitted to $x$ offspring among $p$, with the expected number given by the binomial distribution $\left[\left(\begin{array}{c}x \\ p\end{array}\right) / 2^{p}\right] . n$, assuming a 50 per cent transmission, using a $\chi^{2}$ test for goodness-of-fit (Sokal \& Rohlf, 1981; Jeffreys et al., 1986).

We also calculated the mean transmission frequency
Fig. 2 DNA fingerprints of one parent $\left(\mathrm{P}_{1}\right)$, four of its selfed offspring (1-4) and eight of its outcrossed offspring $(5-12) . P_{2}$ is the father of the outcrossed offspring. Band size $(\mathrm{kb})$ is indicated on the left.

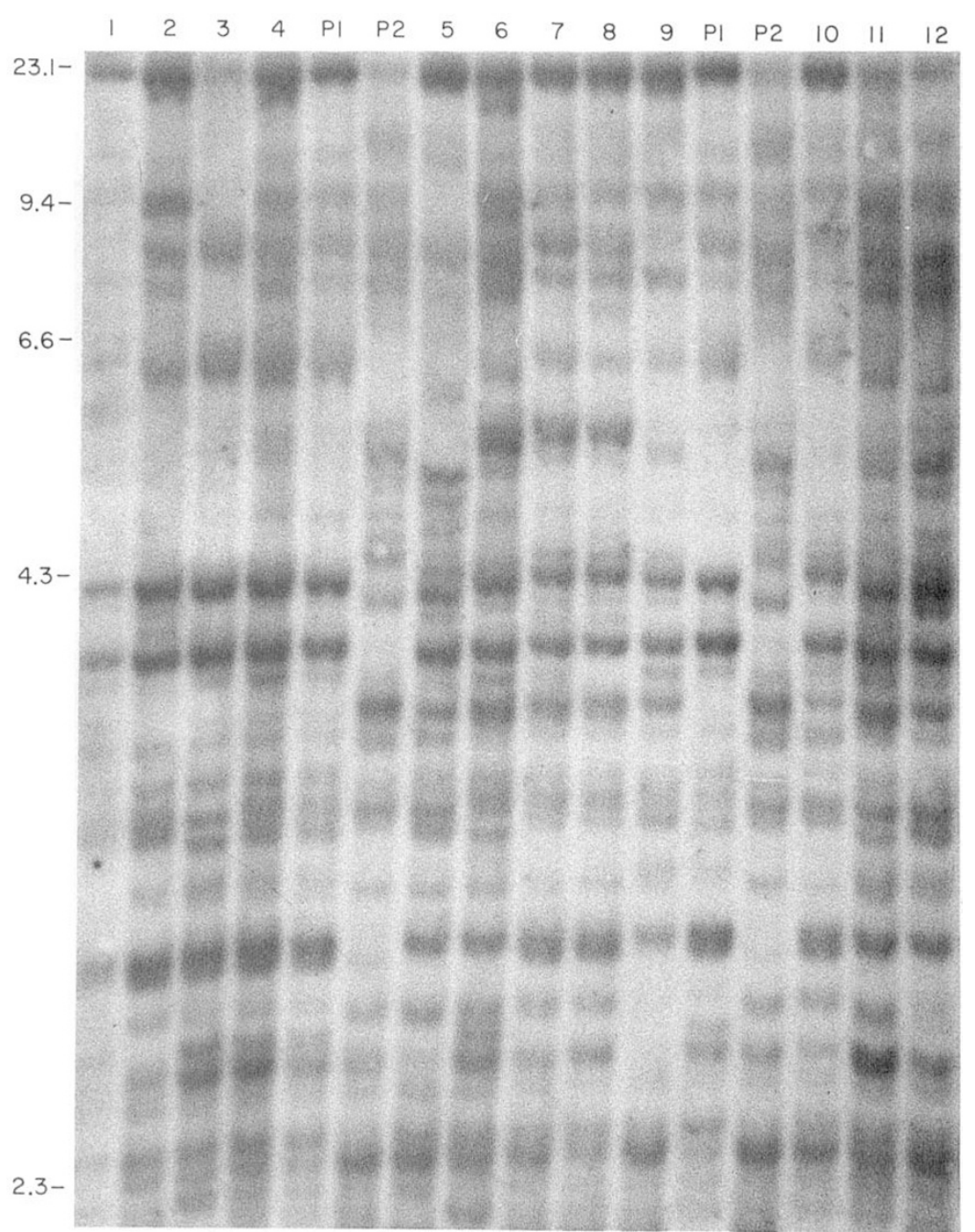


of all bands for mixed broods and that of variable bands. Variable parental band transmission was, as previously, compared to the expected value. In crossfertilization, the transmission was analysed for the fit to a binomial distribution assuming a 50 per cent transmission. The same analysis was performed in selffertilization, assuming a 75 per cent transmission. The binomial distribution was $\left.{ }_{p}^{x}\right) \cdot\left[(3 / 4)^{x} \cdot(1 / 4)^{p-x}\right] . n$. Transmission frequencies were compared between crossfertilization and self-fertilization for the two mothers. We also scored the paternal bands in each outcrossed offspring.

\section{Results}

Examples of fingerprints are given in Fig. 1 and Fig. 2 The transmission frequency of variable and fixed bands for pure selfed, pure outcrossed and mixed broods is given in Tables 2-4 respectively. Variable parental band transmission in outcrossed offspring was consistent with a 50 per cent segregation ratio, as indicated by $\chi^{2}$ values (Tables 2 and 4 ). The transmission of the same bands fitted a binomial distribution

Table 2 Transmission frequency of parental variable bands and all bands with probe $33.15\left(\mathrm{P}_{1}=\right.$ mother; $\mathrm{P}_{2}=$ father $), \chi^{2}$ values for the fit of the total variable band transmission to a 50 per cent value into brackets (none of these values is significant) and $\chi^{2}$ values for the fit of the variable band transmission to a binomial distribution for pure outcrossed broods

\begin{tabular}{|c|c|c|c|c|c|c|c|}
\hline \multirow{3}{*}{\multicolumn{2}{|c|}{ Brood }} & \multicolumn{4}{|c|}{$\begin{array}{l}\text { Mean transmission* } \\
\text { of parental bands }\end{array}$} & \multirow{2}{*}{\multicolumn{2}{|c|}{$\chi^{2} \dagger$ d.f. }} \\
\hline & & \multicolumn{2}{|c|}{ Variable } & \multicolumn{2}{|l|}{ All } & & \\
\hline & & $P_{1}$ & $P_{2}$ & $P_{1}$ & $\mathrm{P}_{2}$ & $P_{1}$ & $\mathbf{P}_{2}$ \\
\hline 1 & $n$ & $\begin{array}{l}8 \\
0.580 \\
0.027 \\
(0.0)\end{array}$ & $\begin{array}{l}10 \\
0.463 \\
0.033 \\
(0.0)\end{array}$ & $\begin{array}{l}13 \\
0.727 \\
0.093\end{array}$ & $\begin{array}{l}15 \\
0.640 \\
0.104\end{array}$ & $\begin{array}{l}3.1 \mathrm{~ns} \\
8\end{array}$ & $\begin{array}{l}2.1 \mathrm{~ns} \\
8\end{array}$ \\
\hline 2 & $n$ & $\begin{array}{l}7 \\
0.524 \\
0.123 \\
(0.0)\end{array}$ & $\begin{array}{l}11 \\
0.474 \\
0.099 \\
(0.1)\end{array}$ & $\begin{array}{l}12 \\
0.722 \\
0.072\end{array}$ & $\begin{array}{l}16 \\
0.638 \\
0.068\end{array}$ & $\begin{array}{l}3.7 \mathrm{~ns} \\
9\end{array}$ & $\begin{array}{l}7.4 \mathrm{~ns} \\
9\end{array}$ \\
\hline 3 & $n$ & $\begin{array}{l}10 \\
0.510 \\
0.194 \\
(0.2)\end{array}$ & $\begin{array}{l}11 \\
0.496 \\
0.117 \\
(0.9)\end{array}$ & $\begin{array}{l}16 \\
0.698 \\
0.119\end{array}$ & $\begin{array}{l}17 \\
0.676 \\
0.085\end{array}$ & $\begin{array}{l}2.1 \mathrm{~ns} \\
13\end{array}$ & $\begin{array}{l}6.6 \mathrm{~ns} \\
13\end{array}$ \\
\hline
\end{tabular}

\footnotetext{
* The transmission frequencies are given with their standard deviation in italics.

$\dagger \mathrm{ns}=$ not-significant.

$n=$ the number of parental bands.
}

(Table 2 and 4). In mixed offspring broods, variable maternal bands in selfing were transmitted to about 75 per cent of the offspring in one pair, while the value was higher for the other pair. The transmission of bands, however, was no different from a binomial distribution, assuming a 75 per cent transmission (Table 4). The mean number of bands transmitted by the father and its extreme values are indicated in Table 5. No individual received less than three bands from his father, when one or the other probe was used. This value increased when the paternal bands obtained with the two probes were added.

In all broods, the transmission frequency was higher when all bands were taken into account (Tables 2-4). This results from two to nine fixed bands per parent snail.

\section{Discussion}

Variable genetic markers are needed to investigate the mating system of freshwater hermaphrodite snails. DNA fingerprinting has been shown to detect such markers in B. globosus (Jarne et al., 1990). We confirm here that highly variable patterns and Mendelian inherited bands are obtained when $B$. globosus is hybridized with the human 33.6 and 33.15 probes. The mean transmission of the variable bands can be assumed to be 50 per cent in cross-fertilization and 75 per cent in self-fertilization.

DNA fingerprinting was used in this study to compare patterns of outcrossed and selfed offspring. The comparison of pure selfed and pure outcrossed broods indicated that the mean transmission frequency is

Table 3 Transmission frequency of parental bands with probes 33.6 and 33.15 for selfed broods

\begin{tabular}{llll}
\hline & & \multicolumn{2}{l}{$\begin{array}{l}\text { Mean transmission* of parental } \\
\text { bands }\end{array}$} \\
\cline { 3 - 3 } Brood & & 33.6 & 33.15 \\
\hline 1 & $n$ & 21 & 23 \\
& & 0.810 & 0.782 \\
2 & & 0.121 & 0.069 \\
& $n$ & 18 & 16 \\
& & 0.769 & 0.795 \\
3 & & 0.081 & 0.047 \\
& & 18 & \\
& & & \\
& & 0.777 & \\
\hline
\end{tabular}

* The transmission frequencies are given with their standard deviation in italics.

$n=$ is the number of parental bands. 
Table 4 Transmission frequency of parental variable bands and all bands $\left(P_{1}=\right.$ mother; self $=$ self-fertilization for the mother; $P_{2}=$ father $), \chi^{2}$ values for the fit of the total variable band transmission to a 50 or 75 per cent value into brackets (none of these values is significant) and $\chi^{2}$ values for the fit of the variable band transmission to a binomial distribution for mixed broods

\begin{tabular}{|c|c|c|c|c|c|c|c|c|c|c|}
\hline \multirow[b]{3}{*}{ Brood } & \multirow[b]{3}{*}{ Probe } & \multicolumn{6}{|c|}{ Mean transmission* of parental bands } & & & \\
\hline & & \multicolumn{3}{|c|}{ Variable } & \multicolumn{3}{|l|}{ All } & \multicolumn{3}{|l|}{$\chi \dagger$ d.f. } \\
\hline & & $\mathrm{P}_{1}$ & Self & $P_{2}$ & $\mathbf{P}_{1}$ & Self & $\mathrm{P}_{2}$ & $P_{1}$ & Self & $\mathbf{P}_{2}$ \\
\hline \multirow[t]{6}{*}{1} & 33.6 & 10 & & 4 & 16 & & 10 & & & \\
\hline & & 0.546 & 0.761 & 0.469 & 0.614 & 0.896 & 0.528 & $4.3 \mathrm{~ns}$ & $4.3 \mathrm{~ns}$ & $6.2 \mathrm{~ns}$ \\
\hline & & $\begin{array}{l}0.162 \\
(0.3)\end{array}$ & $\begin{array}{l}0.106 \\
(0.3)\end{array}$ & $\begin{array}{l}0.088 \\
(0.1)\end{array}$ & 0.108 & 0.080 & 0.078 & 9 & 4 & 9 \\
\hline & $33.15 n$ & 7 & & 10 & 16 & & 19 & & & \\
\hline & & 0.500 & 0.769 & 0.522 & 0.638 & 0.847 & 0.625 & $2.5 \mathrm{~ns}$ & $6.8 \mathrm{~ns}$ & $3.0 \mathrm{~ns}$ \\
\hline & & $\begin{array}{l}0.205 \\
(0.0)\end{array}$ & $\begin{array}{l}0.096 \\
(0.2)\end{array}$ & $\begin{array}{l}0.146 \\
(0.1)\end{array}$ & 0.148 & 0.096 & 0.136 & 9 & 4 & 9 \\
\hline \multirow[t]{6}{*}{2} & $33.6 n$ & 9 & & 7 & 12 & & 8 & & & \\
\hline & & 0.455 & 0.825 & 0.527 & 0.659 & 0.890 & 0.811 & $4.1 \mathrm{~ns}$ & $2.0 \mathrm{~ns}$ & $7.3 \mathrm{~ns}$ \\
\hline & & $\begin{array}{l}0.088 \\
(0.0)\end{array}$ & $\begin{array}{l}0.150 \\
(0.6)\end{array}$ & $\begin{array}{l}0.263 \\
(0.0)\end{array}$ & 0.055 & 0.093 & 0.105 & 8 & 4 & 8 \\
\hline & $33.15 n$ & 13 & & 11 & 18 & & 14 & & & \\
\hline & & 0.492 & 0.821 & 0.522 & 0.777 & 0.922 & 0.748 & $2.5 \mathrm{~ns}$ & $3.2 \mathrm{~ns}$ & $8.7 \mathrm{~ns}$ \\
\hline & & $\begin{array}{l}0.125 \\
(0.0)\end{array}$ & $\begin{array}{l}0.179 \\
(0.1)\end{array}$ & $\begin{array}{l}0.178 \\
(0.1)\end{array}$ & 0.055 & 0.078 & 0.094 & 8 & 4 & 8 \\
\hline
\end{tabular}

* The transmission frequencies are given with their standard deviation in italics.

†ns $=$ not. significant.

$n$ the number of parental bands.

higher in self-fertilization than in cross-fertilization $\left\langle G^{-}\right.$ test for overall number of bands transmitted; $G=16.4$, $P<0.001)$, although there were more fixed bands in the snails studied for cross-fertilization than in those for self-fertilization. When self-fertilization and crossfertilization were further compared within the offspring of the same individual, two differences appeared. First, the mean transmission of variable bands was around 75 per cent in self-fertilization and 50 per cent in cross-fertilization. When all the bands were taken into account, these values increased, as shown for pure selfed and outcrossed broods. However, as long as the mother is not too homozygous, these results indicate that the large number of bands revealed is sufficient to classify the offspring as selfed when they have 75 per cent or more of the variable maternal bands, and as outcrossed when they have 50 per cent or less of the variable maternal bands. All individuals, however, cannot be unambiguously classified. The distribution of bands in offspring fits a binomial distribution with a mean of 0.50 in cross-fertilization and 0.75 in selffertilization. It can be shown by equating the probabili-
Table 5 Mean number of paternal variable bands and extreme individual values in outcrossed offspring of the mixed broods for the two probes

\begin{tabular}{lll}
\hline Brood & 33.6 & 33.15 \\
\hline 1 & $3.752[3-5]$ & $5.742[4-9]$ \\
2 & $2.108[1-3]$ & $4.698[3-9]$ \\
\hline
\end{tabular}

ties that, if $n$ is the total number of variable bands of the mother and $k$ that of an offspring, the probability of being selfed or outcrossed is the same when $k=(\log 2)$ $\log 3)$.n. Individuals with this number of bands cannot be classified as selfed or outcrossed, which result from a large overlap of the distributions in self-fertilization and cross-fertilization. Thus, another difference is needed to distinguish selfed from outcrossed individuals. The number of paternal bands must be analysed for each individual. In our study, each outcrossed individual inherited at least three paternal bands when analysed with one or the other probe. It can be objected that non-maternal bands in offspring patterns 
may result from mutations, as minisatellite loci show high mutation rates of up to 5 per cent per gamete and per locus in man (Jeffreys et al, 1988). However, three non-maternal bands in one offspring pattern, with the same apparent molecular weight as three paternal bands, are likely to arise simultaneously by mutation. Moreover, the number of paternal bands increased when the two probes were used as 33.6 and 33.15 did not give the same patterns, a result which has been generally observed in other species (see Burke, 1989). This increases the probability of classifying individuals without error as selfed or outcrossed.

Thus, a major result of our study is that it is possible to distinguish between selfed and outcrossed offspring even when only the mother is known. In the latter case, the presence of at least three non-maternal bands characterizes the outcrossed offspring.

Some individuals in our experiments had a high number of fixed bands. This could reflect both the homozygosity of natural populations and/or subsequent inbreeding effects in the laboratory. Even in such cases, however, it was possible to distinguish unambiguously between selfed and outcrossed individuals. DNA fingerprinting thus constitutes a promising tool for a precise analysis of the mating system in $B$. globosus. It now becomes possible to test whether selffertilization could be selected and regularly used in some populations. Multiple copulations and sperm competition could also be investigated. Preliminary experiments are necessary under laboratory conditions with non-inbred snails to tests how many fathers could be involved in the offspring of one mother.

\section{Acknowledgements}

The authors thank L. Finot for excellent help, J. Britton-Davidian, F. Kjellberg and one anonymous referee for critical reading of the manuscript and linguistic comments. This work was supported by a CNRSPIREN grant (HIB) and by ORSTOM (Montpellier).

\section{References}

BRown, D. S. 1980. Freshwater Snails of Africa and Their Medical Importance. Taylor \& Francis, London.

BURKE, T. 1989. DNA fingerprinting and other methods for the study of mating success. Trends Ecol. Evol., 4, 139-144.

BURKE, T. AND BRUFORD, M. W. 1987. DNA fingerprinting in birds. Nature, 327, 149-152.

CUNY, G., VEAS, F. AND ROIZES, G. 1990. 'Pocket-blotting' a method for transferring nucleic acids onto Nylon membranes. Anal. Biochem., 193, 45-48.

DALLAS, J. F. 1988. Detection of DNA 'fingerprints' of cultivated rice by hybridization with a human minisatellite
DNA probe. Proc. Nat. Acad. Sci., U.S.A., 85, 68316835.

FEINBERG, A. P. AND vogelstein, B. 1983. A technique for radiolabelling DNA restriction endonuclease fragments to high specific activity. Anal. Biochem., 132, 6-13.

JARNE, P., DELAY, B., BELLEC, C., ROIZES, G. AND CUNY, G. 1990. DNA fingerprinting in schistosome-vector snails. Biochem. Genet., 28, 577-583.

JEFFREYS, A. J. AND MORTON, D. B. 1987. DNA fingerprints of dogs and cats. Anim. Genet., 18, 1-15.

JEFFREYS, A. J., WILSON, v. AND THEIN, S. L. 1985. Hypervariable 'minisatellite' regions in human DNA. Nature, 314, 67-73.

JEFFREYS, A. J., WILSON, V. THEIN, S. W., WEATHERALL, D. J. AND PONDER, B. A. 1986. DNA 'fingerprints' and segregation analysis of multiple markers in human pedigrees. Am.J. Hum. Genet., 39, 11-24.

JEFFREYS, A. J., ROYLE, N. J., WILSON, v, AND WONG, Z. 1988. Spontaneous mutation rates to new length alleles at tandemrepetitive hypervariable loci in human DNA. Nature, 332, 278-281.

JELNES, J. E. 1986. Experimental taxonomy of Bulinus (Gastropoda: Planorbidae): the West and North African species reconsidered, based upon an electrophoretic study of several enzymes per individual. Zoo. J. Linn. Soc., 87, $1-26$.

MANIATIS, T., FRITSCH, E. F. AND SAMBRooK, J. 1982. Molecular Cloning: A Laboratory Manual, Cold Spring Harbor Laboratory, NY.

MENG, A., CARTER, R. E. AND PARKIN, D. T. 1990. The variability of DNA fingerprints in three species of swan. Heredity, 64, 73-80.

NAKAMARA, Y., LEPPERT, M., O'CONNELl, P., WOLFF, R., HOLM, T., CULVER, M., MARTIN, C., FUJIMOTO, E., HOFF, M., KUMLIN, E. AND WHITE, R. 1987. Variable number of tandem repeat (VNTR) markers for human gene mapping. Science, $\mathbf{2 3 5}$, 1616-1622.

RICHARDS, C. S. 1973. Genetics of Biomphalaria glabrata (Gastropoda: Planorbidae). Malac. Rev., 45, 199-202.

ROLlinSON, D. 1984. Recent advances in the characterisation of schistosomes and their intermediate snail hosts. In: Tropical Diseases Research Series, WHO, Geneva, pp. 401-441.

ROLLINSON, D., KANE, R. A. AND LiNES, J. R. L. 1989. An analysis of fertilization in Bulinus cernicus (Gastropoda: Planorbidae). J. Zool., 19, 295-310.

RUDOLPH, P. H. 1983. Copulatory activity and sperm production in Bulinus globosus (Gastropoda: Planorbidae). J. Mol. Stud., 49, 125-132.

RUDOLPH, P. H. AND BAILEY, J. F. 1985. Copulation as females and use of allosperm in the freshwater snail genus Bulinus (Gastropoda: Planorbidae). J. Mol. Stud., 51, 267-275.

SOKAL, R. R. AND ROHLF, F. J. 1981. Biometry, 2nd ed. Freeman, New York.

VIANEY-LIAUD, M. 1989. Growth and fecundity in a blackpigmented and an albino strain of Biomphalaria glabrata (Gastropoda: Pulmonata). Malac. Rev., 22, 25-32.

WETTON, J. H., CARTER, R. E., PARKIN, D. T. AND WALTERS, D. 1987. Demographic study of a wild house sparrow population by DNA fingerprinting. Nature, 327, 147-149. 